\title{
Bacteria in COPD; their potential role and treatment
}

\author{
Paul T King ${ }^{1,2^{*}}$, Martin MacDonald ${ }^{1,2}$ and Philip G Bardin ${ }^{1,3}$
}

\begin{abstract}
The role of bacterial infection in chronic obstructive pulmonary disease (COPD) and how it should be treated has been an ongoing source of controversy. For many years bacterial infection has not been thought to have an important effect in the pathology of this condition. Recent advances in diagnostic techniques, particularly the use $16 \mathrm{~S}$ sequencing has demonstrated that there are a large range of bacteria present in the lower respiratory tract, both in terms of exacerbations and chronic colonization. A proportion of the bacteria present in the lower respiratory have also been shown to produce inflammation and hence are likely to be relevant for the pathogenesis of COPD. The accurate diagnosis of bacterial infection in individual patients remains a major challenge. The trials that have assessed the effect of antibiotics in COPD have generally been of low quality and have not been placebo controlled. Recent studies of macrolides for long-term treatment in COPD have found significantly reduced rates of exacerbations. Major challenges remain in accurately defining the potential role of bacteria in the inflammatory process and how best to optimize the use of antibiotics without the overuse of this limited resource. Alternative strategies to treat infection in COPD remain very limited.
\end{abstract}

\section{Review}

The role of bacterial infection in COPD and how it should be treated has been an ongoing source of controversy. The British hypothesis proposed that recurrent bronchial infections were the reason that some smokers developed airflow obstruction while others did not $[1,2]$. The subsequent study of Fletcher and Peto demonstrated that chronic bronchitis and respiratory infections did not relate to lung function decline [3]. As a consequence for many years it was believed that the chronic bronchitis syndrome had no relevance to lung function decline in COPD. However more recent studies have described a relationship between lung function decline and respiratory infections. Chronic bronchitis [4], respiratory infections [5,6] and sputum bacterial counts [7]; have been shown to be related to decline in lung function in COPD. The role of chronic bronchitis remains controversial though.

\footnotetext{
* Correspondence: paul.king@monash.edu

${ }^{1}$ Monash Lung and Sleep, Monash Medical Centre, 246 Clayton Road,

Clayton, Melbourne 3168, Australia

${ }^{2}$ Department of Medicine, Monash Medical Centre, Monash University,

Melbourne, Australia

Full list of author information is available at the end of the article
}

A relatively recently realized feature of COPD is intense bronchial inflammation; that persists despite the cessation of smoking and is most prominent in advanced disease $[8,9]$. The factors that drive the inflammatory process after smoking cessation have not been clearly defined [10]. Bacterial infection is one potential candidate and bacteria can induce inflammation both in the context of exacerbations and in the stable baseline state.

Antibiotics have been used as standard management for the treatment of exacerbations of COPD, but their value in this context remains uncertain [11]. Recent trials of the long-term use of macrolides have shown promising results [12].

This review will discuss the role of bacteria in the pathogenesis of COPD. Methods of diagnosing respiratory infection will be reviewed and the potential effect of antibiotics and other therapies in treatment.

\section{Microbiology of the respiratory tract}

Bacteria have established niches in the human body where they exist in symbiosis with their host. The term microbiome is used to refer to complex communities of microorganisms, termed the microbiota, that inhabit the body surfaces in symbiosis with the host [13]. The most clearly defined microbiome occurs in the gastrointestinal

\section{实}


tract in which there are far more bacterial cells than in the whole human body (as bacteria are much smaller than human cells). Bacteria which form part of the normal flora of the microbiome, are tolerated by the local mucosal immune response with minimal activation of inflammatory cells, in particular T cells [14]. Significant recent advances in the understanding of the human microbiome have been facilitated by the detection of the highly conserved $16 \mathrm{~S}$ ribosomal RNA present in bacteria. The $16 \mathrm{~S}$ ribosome is present on bacterial (but not human) cells [15]. Using $16 \mathrm{~S}$ sequencing it has become apparent that there are a vast number of different bacteria present in the normal human body.The upper respiratory tract (especially the nasopharynx and the mouth) is densely colonized by a large variety of bacteria [16]. The colonization of this microbiome is a dynamic process with frequent turnover of different strains. A number of these bacteria are potentially pathogenic micro-organisms (PPM) if they move into the lower respiratory tract [17]. These potential pathogens may colonize the upper airway for long periods such as Haemophilus influenzae, Moxarella catarrhalis and Streptococcus pneumoniae or for transient periods such as Mycoplasma pneumoniae [18,19]. A recent study has described that the depletion of the normal microbiome is associated with an increased prevalence of Corynebacterium tuberculostearium that mediates rhinosinusitis; this pathogen could potentially have a role in the lower respiratory tract [20].

The lower respiratory tract is directly connected to the upper respiratory tract with frequent micro-aspiration of secretions. With the use of $16 \mathrm{~S}$ sequencing it has been recently recognized that the lower respiratory tract is in fact not sterile but contains a variety of bacteria [16]. The bacteria present in the lower respiratory tract could be quickly cleared by host defense, may persist as pathogens causing ongoing inflammation or form a lower respiratory tract microbiome (i.e. bacteria exist in symbiosis with the host). It has also become apparent that patients with chronic airways disease (asthma and COPD) have a different spectrum of bacteria in the lower respiratory tract than those with normal lungs [15,21-25]. These studies have generally found a close correlation between the upper and lower airway microbiome. It should be emphasized that defining the lower airway bacteria is challenging and the studies done so far have had small numbers. The quality of the data varies and studies have used a range of techniques to sample the lower airway. Recent studies of the lower respiratory tract microbiome are listed in Table 1.

Several studies have demonstrated the presence of bacteria particularly $H$. influenzae in surgical lung tissue in patients with COPD [26,27]. The ability of bacteria to invade into the respiratory tract and persist for long

Table 1 Studies of the lung microbiome in COPD

\begin{tabular}{|c|c|c|c|}
\hline Study & Subjects (n) & Sample & Key findings \\
\hline \multirow[t]{3}{*}{ Hilty et al. 2010 [21] } & 8 Control & \multirow[t]{3}{*}{ BAL/Brush } & \multirow[t]{3}{*}{ Pathogenic bacteria, e.g. H. influenzae in asthma and COPD subjects } \\
\hline & 11 Asthma & & \\
\hline & 5 COPD & & \\
\hline \multirow[t]{2}{*}{ Charlson et al. 2010 [22] } & 29 Smoker & \multirow[t]{2}{*}{ Pharynx } & \multirow{2}{*}{$\begin{array}{l}\text { Different regions of pharynx have different microbial communities which are changed by } \\
\text { smoking }\end{array}$} \\
\hline & $\begin{array}{l}33 \text { Non- } \\
\text { smoker }\end{array}$ & & \\
\hline \multirow{3}{*}{$\begin{array}{l}\text { Erb-Downward et al. } 2011 \\
\text { [23] }\end{array}$} & 9 Control/ & \multirow[t]{3}{*}{ BAL } & \multirow[t]{3}{*}{ Core pulmonary microbiota in BAL \& lung tissue } \\
\hline & 5 COPD & & \\
\hline & 6 severe $\mathrm{COPD}$ & & \\
\hline \multirow[t]{4}{*}{ Sze et al. 2012 [24] } & 8 Control & \multirow{4}{*}{$\begin{array}{l}\text { Lung } \\
\text { tissue }\end{array}$} & \multirow[t]{4}{*}{ Differences in bacterial communities in the same lung } \\
\hline & $8 \mathrm{COPD}$ & & \\
\hline & 8 severe COPD & & \\
\hline & $\begin{array}{l}8 \text { Cystic } \\
\text { fibrosis }\end{array}$ & & \\
\hline \multirow[t]{2}{*}{ Pragmann et al. 2012 [25] } & 10 Control & \multirow[t]{2}{*}{ BAL } & \multirow[t]{2}{*}{ Detectable bacterial communities in lung tissue that changes in severe COPD } \\
\hline & 22 COPD & & \\
\hline \multirow[t]{2}{*}{ Morris et al. 2013 [15] } & 32 Smoker & \multirow[t]{2}{*}{ Oral wash } & \multirow[t]{2}{*}{ Mouth communities different in smoker } \\
\hline & $\begin{array}{l}30 \text { Non- } \\
\text { smoker }\end{array}$ & & \\
\hline
\end{tabular}


periods either between or inside cells may also be potentially important [28].

\section{The potential role of bacteria in COPD}

COPD is characterized by airway inflammation that causes progressive pulmonary damage. The primary risk factor is smoking which has a variety of pathogenic effects on the airway. However it has been recognized that airway inflammation persists after smoking cessation [8]. Hogg et al. have described the presence of lymphoid follicles in the airway walls of ex-smokers that have a key role in driving inflammation and airflow obstruction [9]. These lymphoid follicles are likely to be resulting from the presence of persistent lung antigen but what this could be has not been well defined. Potential antigens include autoimmune antibodies, embedded heavy metals from smoking and bacterial infection [29].

Smoking has a number of long-term effects on the lung host defense that persist after smoking cessation and increase the risk of secondary bacterial infection [30]. These include permanent structural damage and changes in the function of host immune cells including macrophages, NK cells, dendritic cells and lymphocytes.

The ability of bacteria to cause disease is primarily related to overcoming the protective host immune response. Both the structural airway integrity and cellular immune response have a critical role. The airways secrete anti-microbial peptides such as defenses which control microflora [31]. Rhinovirus infections can downregulate the production of these peptides and this may be important in exacerbations of COPD [32].

\section{Presence of bacteria in exacerbations of COPD}

A factor put forward for the relevance of bacteria in COPD is their strong association with exacerbations. Approximately $50 \%$ of exacerbations of COPD are associated with the isolation of bacteria from the lower respiratory tract $[33,34]$. The dominant bacterium are; $H$. influenzae, S. pneumoniae and Moxarella catarrhalis. In advanced disease $P$. aeruginosa becomes more prevalent [34]. There are challenges in obtaining a representative sample; but studies of sputum and bronchoscopy samples using standard culture and molecular techniques have clearly demonstrated that COPD exacerbations are associated with a markedly increased prevalence of bacteria.

The bacteria that are associated with exacerbations could potentially be new strains of bacteria from the upper respiratory tract or from chronic colonization of the lower respiratory tract. Sethi and colleagues have described that the acquisition of a new strain of bacteria (particularly $H$. influenzae) is associated with COPD exacerbations $[35,36]$. However only a minority of exacerbations were associated with the acquisition of a new strain. It has been difficult to define, but $38-73 \%$ of patients with stable COPD have been described to have the presence of PPMs on baseline sputum [7,37-41], and on bronchoscopy between 33-50\% [42-44]. Exacerbations could arise in the context of these resident bacteria. Similar to the upper airway the lower airway bacterial colonization is a dynamic process with turnover of strains.

A recently described entity is bacterial and viral coinfection. This may be present in up to $25 \%$ of exacerbations and is associated with worse clinical outcomes and more severe disease $[37,45,46]$. The viral infection may down-regulate host defense leading to enhanced bacterial proliferation and inflammation. Malia et al. have recently demonstrated that experimental rhinovirus infection is associated with a very high rate of bacterial exacerbation in COPD patients [32].

\section{Bacteria and decline in lung function}

There is indirect evidence correlating the decline in lung function with airway infection and chronic bronchitis in COPD $[47,48]$. Chronic bronchitis, respiratory infections and sputum bacterial counts have been shown to be related to decline in lung function in COPD. The studies that have been done in this regard have generally been cross-sectional rather than longitudinal. The demonstration that the clearance of bacteria is associated with improved lung function would be an important advance.

\section{Role of bacteria in inflammation}

COPD is characterized by persistent inflammation that damages lung tissue, causing airflow obstruction. This inflammation persists after smoking. Neutrophils, macrophages and $\mathrm{T}$ cells produce mediators such as cytokines, reactive oxygen species and proteases to drive this process $[10,29,49]$. Whilst it is generally accepted that bacteria are very commonly found in the airways in COPD, their role in the inflammatory process is less well defined.

\section{In exacerbations of COPD}

Two studies have reported increased levels of the inflammatory mediators, interleukin (IL) 8, tumor necrosis factor alpha (TNF- $\alpha$ ), neutrophils and elastase with bacteria $[50,51]$. Other studies have found that bacterial exacerbations were associated with an increase in a variety of parameters including neutrophils, eosinophils, TNF- $\alpha$, IL-1, CCL 5, CCL3 and CXCL11 [52-57]. Sethi et al. found that the presence of $H$. influenzae and $M$. catarrhalis was associated with increased sputum inflammatory markers [58]. 


\section{Lower airway bacterial colonization}

This may also contribute to chronic airway inflammation. White et al. showed that resolution of inflammation after an exacerbation is dependent on bacterial clearance; when this does not occur there may be ongoing inflammation [59]. Chronic airway colonization has been shown to be related to the frequency and severity of exacerbations $[7,40,60]$ and sputum inflammatory markers $[41,60]$. In stable patients airway colonization has been demonstrated to have increased levels of airway inflammatory markers including TNF- $\alpha$, IL-1, IL-6, IL-12, matrix metalloproteinase (MMP), myeloperoxidase and neutrophil elastase [38,41,42,60-62]. The load of bacteria has been described to be related to the exacerbations and inflammation; using both culture [7] and molecular techniques [63] although other researchers have come to different conclusions [36].

Lymphocyte are recognized to have a key role in driving inflammation in COPD but the antigens that activate these cells have not been well defined. We have recently demonstrated that nontypeable Haemophilus influenzae (NTHi) strongly activates T cells obtained from surgical lung tissue to cause a proinflammatory, profibrotic response that also enhances airway reactivity [64]. This work suggests that NTHi has a role in driving T cell mediated inflammation in COPD. Factors which suggest a role for bacteria in the pathogenesis of COPD are summarized in listed below.

\section{Factors that imply a potential role for bacteria in COPD}

1. Present in approximately $50 \%$ of lower airway samples in exacerbations

2. Colonize the airways in approximately $33-73 \%$ of COPD patients

3. Chronic bronchitis, respiratory infections and sputum bacterial counts are associated with lung function decline

4. Bacteria are associated with increased inflammatory markers in exacerbations

5. Chronic airway colonization is related to the frequency and severity of exacerbations and to levels of airway inflammatory markers

6. Bacteria activate lung T cells in COPD to produce a pro-inflammatory response

\section{Diagnosis of bacteria and infection}

The available literature suggests that bacteria are an important cause of inflammation in COPD however this is probably only in a proportion of patients. COPD is a heterogeneous condition and recent efforts have been made to phenotype this condition. Patients with chronic bronchitis and with frequent exacerbations could represent a phenotype associated with bacterial infection
$[47,65]$. The evidence that the identification of specific bacteria changes treatment outcomes is minimal. However this may change with better quality studies and newer techniques.

Sputum samples are the first-line investigation used. Stockley et al. have established that the production of purulent sputum that is graded on a color scale (from white to dark green; as a marker of neutrophils) is strongly associated with bacterial infection [66,67]. A good quality specimen that is representative of the lower airway should have; < 10 squamous epithelial cells and $>25$ polymorphs in low power field $[68,69]$. Sputum culture results have the highest validity when they are consistent with the gram stain (e.g. G-ve bacilli on gram stain accompanied by growth of $P$. aeruginosa on culture) [70,71]. The use of nucleic acid amplification tests (NAAT) may increase the yield of fastidious pathogens such as M. pneumoniae and C. pneumoniae [72,73].

The diagnostic yield may be increased by the use of bronchoscopy. There is a significant issue of potential contamination as the bronchoscope is initially passed through the upper airway. The protected specimen brush is more specific than the bronchoalveolar lavage (BAL) although it does have the issue of only obtaining small specimen amounts [74]. Using a cut off of colony forming units (CFU) of bacteria per $\mathrm{ml}$ of specimen (e.g. $10^{3} \mathrm{ml}$ ) increases sensitivity $[75,76]$. As described previously $16 \mathrm{~S}$ sequencing has given a new perspective on the lower airway; at this stage it is primarily a research tool but in time is likely to become more mainstream.

There may also be significant merit in taking bronchial biopsies or examining surgical lung specimens for the presence of bacteria as this tissue should be sterile. Patel et al. described the presence of intracellular $H$. influenzae in 14/15 patients having an exacerbation of COPD (and none in controls) [40]. Moller et al. examined the explants of patients with COPD (and other conditions) and found widespread invasion of lung tissue with intracellular $H$. influenzae in half of the subjects [77]. More recently, Droman et al. described the presence of this bacterium in the lung tissue in $40 \%$ of patients in all stages of COPD [27].

\section{Use of antibiotics in COPD}

There is a lack of good quality trials concerning the effectiveness of antibiotics for the treatment of COPD and this more than anything has contributed to the controversy about the role of bacteria in the pathogenesis of this condition.

\section{Use of antibiotics for exacerbations of COPD}

There have been a number of problems with the antibiotic trials in COPD exacerbations; particularly with issues of lack of placebo control, poorly defined patient 
groups, lack of follow-up data and the endpoints measured $[78,79]$. In many trials it has been felt that it is not ethical to withhold antibiotics (i.e. use a placebo) so typically designs have compared one antibiotic with another $[78,80]$.

Perhaps the best study to date is that of Anthonisen et al. who used a randomized, double-blind design [81]. They defined three cardinal symptoms of increasing; 1) dyspnea 2), sputum volume and 3) sputum purulence. Subjects who had two symptoms (type 2) or three symptoms (type 1) had a modest benefit from antibiotics (subjects with one symptom had no benefit).

A recent Cochrane review assessed the use of antibiotics for exacerbations of COPD [11]. Sixteen randomized controlled trials of 2068 subjects were included. In mild exacerbations they found there was evidence of low quality that antibiotics significantly reduced the risk of treatment failure 7 days to one month after treatment initiation. Evidence of high quality demonstrated a significant reduction in treatment failure in in-patients with severe exacerbations. Evidence of moderate quality demonstrated an increased risk of side effects with antibiotics (particularly diarrhea).

A recent trial by Llor et al. evaluated the effect of antibiotics in an ambulatory population of mild-moderate exacerbations [82]. This trial randomized patients to be either treated with amoxicillin/clavulanate $(n=117)$ or placebo $(n=91)$. They found that the use of antibiotics was more effective and significantly prolonged the time to next exacerbation when compared to placebo. This is the first trial to show a clear benefit in the outpatient setting and one of the few trials that has used a placebo.

Other criteria have been proposed as being useful in determining whether antibiotics are indicated for exacerbations. Sputum purulence is correlated with bacterial infection [67] and withholding antibiotics in those without purulent sputum may be safe $[67,83]$. Procalcitonin is a marker of bacterial infection and may be a useful guide as to whether antibiotics are indicated $[84,85]$. The most commonly used biomarker in COPD is the Creactive protein (CRP). Llor et al. found that a CRP of > $40 \mathrm{mg} / \mathrm{L}$ in the placebo group predicted clinical failure [82]. The role of biomarkers as a marker of inflammation in COPD is an area of active research with several recent large studies published. MacNee has recently reviewed this topic [86] and has highlighted the role of the lung-specific factors CCL-18/PARC and SP-D, which are closely correlated with clinical outcomes (e.g. exacerbations) and anti-inflammatory therapy; fibrinogen whilst less organ specific may also be helpful.

\section{Use of antibiotics in stable COPD}

There is increasing evidence that bacteria contributes to lung inflammation both in exacerbations and in stable
COPD. Antibiotics have used for the treatment of chronic bronchitis for many years with trials first done 50 years. Staykova et al. reviewed the early trials and found a small reduction in days of illness in exacerbations [87]. Due to lack of good data and concerns about antibiotic resistance this approach was rarely used for the management of stable COPD. However this has changed recently with a series of trials that have used macrolides.

Seemungal et al. assessed a cohort of 109 patients randomized to treatment with erythromycin or placebo for a year and found there was a significant reduction in exacerbations in the erythromycin group [88]. A major study of 1142 subjects who were randomized to treatment with azithromycin $250 \mathrm{mg}$ daily or placebo for a year found a significant reduction in exacerbations and improvement in quality of life in the treatment arm [12]. Several other studies have found that macrolides reduce exacerbations of COPD [89-91]. The mechanisms by which macrolides reduce exacerbations are unknown.

There is significant overlap with bronchiectasis and COPD. Two trials have reported in COPD a prevalence of bronchiectasis of $29 \%$ and $50 \%$ [92,93]. Two studies have found improved outcomes in cohorts of bronchiectasis patients treated with macrolides. Wong et al. demonstrated that the use of azithromycin at $500 \mathrm{mg}$ three times a week significantly reduced exacerbations when compared to control [94]. Similarly Serisier et al. found that the use of erythromycin $400 \mathrm{mg}$ twice daily for 12 months reduced exacerbations when compared to control [95].

There are some potential problems with the use of macrolides to prevent exacerbations [96]. Azithromycin has a mildly increased risk of hearing deficits and prolonged QT syndrome with a one study reported a slightly increased risk of cardiac death [97]. However a more recent study found no increased risk of cardiac death [98]. Macrolides should probably be given with caution to subjects with significant cardiac or vascular disease. There are drug interactions especially with statins, warfarin and amiodarone. There is also an increased risk of antibiotic resistance including to $S$. pneumoniae and Mycobacterium avium complex. Wenzel et al. recommend that macrolides (azithromycin) should be considered as maintenance therapy in subjects who have at least 2 exacerbations in past year despite optimal therapy and no significant contraindications [96].

\section{Other therapies to treat infection in COPD}

Antibiotics are a limited resource and should be used when there is a strong clinical indication. There is a significant need for other therapeutic modalities to treat infection in the context of COPD. 


\section{Vaccination for COPD}

The influenza and pneumococcal vaccines are a frequent part of standard management of COPD [99]. Viral influenza is associated with increased exacerbations of COPD and a higher risk of hospitalization. A Cochrane review in 2006 found that vaccination resulted in a mildly decreased risk of exacerbations. The vaccine may be given as inactive or attenuated forms and both forms appear safe with no clear differences in efficacy [100].

Streptococcus pneumoniae is a major cause of acute exacerbations of COPD and may also colonize the lower airway. The vaccine has two forms, the valent polysaccharide vaccine and the newer conjugated vaccine. The conjugated vacccine induces a stronger immune response and may potentially be more effective. Three retrospective studies demonstrated a reduction in the incidence of pneumonia, hospitalizations and invasive disease [101-103]. A Cochrane review found a reduction in invasive pulmonary disease after pneumococcal vaccination but no reduction in all-cause pneumonia or mortality [104].

In addition to influenza and pneumococcal vaccination the Centers for Disease Control (CDC) and American Society for Infectious Diseases (ASID) also recommend Pertussis and Herpes Zoster vaccination in patients with COPD. The evidence supporting the use of Pertussis and Herpes Zoster vaccination in this context is minimal.

The nontypeable form of Haemophilus influenzae is the dominant bacterium in patients with COPD and there have been studies of the use of vaccination against this pathogen intermittently for a number of years. An inactivated vaccine has been previously shown to reduce the incidence of acute exacerbations in COPD but was not widely used [105]. A more recent study has again demonstrated that oral vaccination is safe and reduces severe exacerbations [106]. A successful vaccine against $H$. influenzae would be a major advance in management.

\section{Use of corticosteroids}

Systemic corticosteroids are standard therapy for the treatment of COPD exacerbations. The combination of corticosteroids and antibiotics for exacerbations has been demonstrated to improve outcomes when compared to either agent alone [107].

The long-term use of corticosteroids on infection in COPD is not clear-cut. Corticosteroids are potentially beneficial by reducing inflammation, however this results in a down-regulation of host defense and increased risk of infection. Maintenance therapy with inhalational corticosteroids has been shown to reduce the number of exacerbations but conversely increase the rate of pneumonia [108].

\section{Other agents}

As the viral-bacterial co-infection is associated with worse outcomes in COPD there may be a role for antivirals in the treatment of exacerbations. Neuraminidaseinhibitors for the treatment of influenza may be beneficial although there appears to be no clear literature to guide this choice. Recently drugs have been developed against the rhinovirus including the capsid-binding agent, pleconaril [109].

As bacterial infection produces inflammation, the use of anti-inflammatory agents may be useful. Phosphodiesterase inhibitors such as roflumilast and cilomilast reduce inflammation and exacerbations in COPD $[110,111]$. Antioxidants such as $\mathrm{N}$-acetylcysteine in subgroup analysis may reduce exacerbations [112]. Whether these effects are relevant to bacterial infection remains to be determined.

The intestinal microbiome has recently been recognized to have general effects on host immunity including in the lung. Therefore the use of probiotics to enhance normal intestinal flora may have potentially beneficial effects on lung inflammation. Forsythe has reviewed this topic; whilst animal data has shown promising results for the use of probiotics to reduce lung inflammation, human studies have so far been inconclusive [113].

\section{Conclusions}

Increasing evidence has demonstrated that bacteria are very common in the lower respiratory tract of patients with COPD and cause inflammation. Antibiotics have a clear role in the treatment of a proportion of subjects. There are still very large gaps in understanding how bacteria contribute to inflammation in COPD and what are the best methods to diagnose their presence in individual patients. Antibiotics are a limited resource and establishing how they should best be utilized to treat infection in COPD will be a major challenge. The development of alternative therapies is likely to be critical to long-term improvement in management.

Competing interests

The authors have no competing interests in this work.

\section{Authors' contributions}

PK drafted, wrote and reviewed the manuscript. MMD drafted and reviewed the manuscript. PB drafted and reviewed manuscript. The authors all reviewed and approved the final manuscript.

\section{Author details}

${ }^{1}$ Monash Lung and Sleep, Monash Medical Centre, 246 Clayton Road, Clayton, Melbourne 3168, Australia. ${ }^{2}$ Department of Medicine, Monash Medical Centre, Monash University, Melbourne, Australia. ${ }^{3}$ Monash Institute of Medical Research, Monash Medical Centre, Melbourne, Australia.

Received: 8 May 2013 Accepted: 6 August 2013

Published: 30 August 2013 


\section{References}

1. Fletcher CM: Chronic bronchitis. Its prevalence, nature, and pathogenesis. Am Rev Respir Dis 1959, 80:483-494.

2. Anthonisen NR: The British hypothesis revisited. Eur Respir J 2004, 23 (5):657-658.

3. Fletcher $C$, Peto R: The natural history of chronic airflow obstruction. BrMed J 1977, 1(6077):1645-1648.

4. Vestbo J, Prescott E, Lange P: Association of chronic mucus hypersecretion with FEV1 decline and chronic obstructive pulmonary disease morbidity. Copenhagen City Heart Study Group. Am J Respir Crit Care Med 1996, 153(5):1530-1535

5. Kanner RE, Anthonisen NR, Connett JE: Lower respiratory illnesses promote FEV(1) decline in current smokers but not ex-smokers with mild chronic obstructive pulmonary disease: results from the lung health study. Am J Respir Crit Care Med 2001, 164(3):358-364.

6. Donaldson GC, Seemungal TA, Bhowmik A, Wedzicha JA: Relationship between exacerbation frequency and lung function decline in chronic obstructive pulmonary disease. Thorax 2002, 57(10):847-852

7. Wilkinson TM, Patel IS, Wilks M, Donaldson GC, Wedzicha JA: Airway bacterial load and FEV1 decline in patients with chronic obstructive pulmonary disease. Am J Respir Crit Care Med 2003, 167(8):1090-1095.

8. Shapiro SD: End-stage chronic obstructive pulmonary disease: the cigarette is burned out but inflammation rages on. Am J Respir Crit Care Med 2001, 164(3):339-340.

9. Hogg JC, Chu F, Utokaparch S, Woods R, Elliott WM, Buzatu L, Cherniack RM Rogers RM, Sciurba FC, Coxson HO, et al: The nature of small-airway obstruction in chronic obstructive pulmonary disease. N Engl J Med 2004, 350(26):2645-2653.

10. Hogg JC: Pathophysiology of airflow limitation in chronic obstructive pulmonary disease. Lancet 2004, 364(9435):709-721.

11. Vollenweider DJ, Jarrett H, Steurer-Stey CA, Garcia-Aymerich J, Puhan MA: Antibiotics for exacerbations of chronic obstructive pulmonary disease. Cochrane Database Syst Rev 2012, 12, CD010257.

12. Albert RK, Connett J, Bailey WC, Casaburi R, Cooper JA Jr, Criner GJ, Curtis JL, Dransfield MT, Han MK, Lazarus SC, et al: Azithromycin for prevention of exacerbations of COPD. N Engl J Med 2011, 365(8):689-698.

13. Hooper LV, Littman DR, Macpherson AJ: Interactions between the microbiota and the immune system. Science 2012, 336(6086):1268-1273.

14. Murphy K, Travers P, Walport M: T cell-mediated immunity. In Janeway's Immunobiology. 7th edition. Edited by Murphy K, Travers P, Walport M. New York: Garland Science; 2008:323-372.

15. Morris A, Beck JM, Schloss PD, Campbell TB, Crothers K, Curtis JL, Flores SC, Fontenot AP, Ghedin E, Huang $L$, et al: Comparison of the respiratory microbiome in healthy non-smokers and smokers. Am J Respir Crit Care Med 2013, 187(10):1067-1075.

16. Beck JM, Young VB, Huffnagle GB: The microbiome of the lung. Transl Res 2012, 160(4):258-266.

17. Angrill J, Agusti C, De-Celis R, Rano A, Gonzalez J, Sole T, Xaubet A, Rodriguez-Roisin R, Torres A: Bacterial colonisation in patients with bronchiectasis: microbiological pattern and risk factors. Thorax 2002, 57(1):15-19.

18. Pelton SI: Regulation of bacterial trafficking in the nasopharynx. Paediatr Respir Rev 2012, 13(3):150-153.

19. Hurst JR: Upper airway. 3: sinonasal involvement in chronic obstructive pulmonary disease. Thorax 2010, 65(1):85-90.

20. Abreu NA, Nagalingam NA, Song Y, Roediger FC, Pletcher SD, Goldberg AN, Lynch SV: Sinus microbiome diversity depletion and Corynebacterium tuberculostearicum enrichment mediates rhinosinusitis. Sci Trans/ Med 2012, 4(151):151ra124. doi:10.1126/scitransImed.3003783.

21. Hilty M, Burke C, Pedro H, Cardenas P, Bush A, Bossley C, Davies J, Ervine A, Poulter $L$, Pachter $L$, et al: Disordered microbial communities in asthmatic airways. PLoS One 2010, 5(1):e8578.

22. Charlson ES, Chen J, Custers-Allen R, Bittinger K, Li H, Sinha R, Hwang J, Bushman FD, Collman RG: Disordered microbial communities in the upper respiratory tract of cigarette smokers. PLoS One 2010, 5(12):e15216.

23. Erb-Downward JR, Thompson DL, Han MK, Freeman CM, McCloskey L, Schmidt LA, Young VB, Toews GB, Curtis $J$, Sundaram B, et al: Analysis of the lung microbiome in the "healthy" smoker and in COPD. PLOS One 2011, 6(2):e16384.

24. Sze MA, Dimitriu PA, Hayashi S, Elliott WM, McDonough JE, Gosselink JV, Cooper J, Sin DD, Mohn WW, Hogg JC: The lung tissue microbiome in chronic obstructive pulmonary disease. Am J Respir Crit Care Med 2012, 185(10):1073-1080

25. Pragman AA, Kim HB, Reilly CS, Wendt C, Isaacson RE: The lung microbiome in moderate and severe chronic obstructive pulmonary disease. PLoS One 2012, 7(10):e47305.

26. Moller LV, Timens W, van der-Bij W, Kooi K, de-Wever B, Dankert J, van-Alphen L: Haemophilus influenzae in lung explants of patients with end-stage pulmonary disease. Am J Respir Crit Care Med 1998, 157(3 Pt 1):950-956.

27. Dromann D, Rupp J, Rohmann K, Osbahr S, Ulmer AJ, Marwitz S, Roschmann K, Abdullah M, Schultz H, Vollmer E, et al: The TGF-beta-pseudoreceptor BAMBI is strongly expressed in COPD lungs and regulated by nontypeable Haemophilus influenzae. Respir Res 2010, 11:67.

28. King P: Haemophilus influenzae and the lung (Haemophilus and the lung). Clin Transl Med 2012, 1(1):10.

29. Cosio MG, Saetta M, Agusti A: Immunologic aspects of chronic obstructive pulmonary disease. N Engl J Med 2009, 360(23):2445-2454.

30. Stampfli MR, Anderson GP: How cigarette smoke skews immune responses to promote infection, lung disease and cancer. Nat Rev Immunol 2009, 9(5):377-384.

31. Herr C, Shaykhiev R, Bals R: The role of cathelicidin and defensins in pulmonary inflammatory diseases. Expert Opin Biol Ther 2007, 7(9):1449-1461.

32. Mallia P, Footitt J, Sotero R, Jepson A, Contoli M, Trujillo-Torralbo MB, Kebadze T, Aniscenko J, Oleszkiewicz G, Gray K, et al: Rhinovirus infection induces degradation of antimicrobial peptides and secondary bacterial infection in chronic obstructive pulmonary disease. Am J Respir Crit Care Med 2012, 186(11):1117-1124.

33. Sethi S: Infectious etiology of acute exacerbations of chronic bronchitis. Chest 2000, 117(5 Suppl 2):380S-385S.

34. Beasley V, Joshi PV, Singanayagam A, Molyneaux PL, Johnston SL, Mallia P. Lung microbiology and exacerbations in COPD. Int J Chron Obstruct Pulmon Dis 2012, 7:555-569.

35. Sethi S, Evans N, Grant BJ, Murphy TF: New strains of bacteria and exacerbations of chronic obstructive pulmonary disease. $N$ Engl J Med 2002, 347(7):465-471.

36. Sethi S, Sethi R, Eschberger K, Lobbins P, Cai X, Grant BJ, Murphy TF: Airway bacterial concentrations and exacerbations of chronic obstructive pulmonary disease. Am J Respir Crit Care Med 2007, 176(4):356-361.

37. Papi A, Bellettato CM, Braccioni F, Romagnoli M, Casolari P, Caramori G, Fabbri LM, Johnston SL: Infections and airway inflammation in chronic obstructive pulmonary disease severe exacerbations. Am J Respir Crit Care Med 2006, 173(10):1114-1121

38. Marin A, Monso E, Garcia-Nunez M, Sauleda J, Noguera A, Pons J, Agusti A, Morera J: Variability and effects of bronchial colonisation in patients with moderate COPD. Eur Respir J 2010, 35(2):295-302.

39. Miravitlles M, Marin A, Monso E, Vila S, de la-Roza C, Hervas R, Esquinas C, Garcia M, Millares L, Morera J, et al: Colour of sputum is a marker for bacterial colonisation in chronic obstructive pulmonary disease. Respir Res 2010, 11:58.

40. Patel IS, Seemungal TA, Wilks M, Lloyd-Owen SJ, Donaldson GC, Wedzicha JA: Relationship between bacterial colonisation and the frequency, character, and severity of COPD exacerbations. Thorax 2002, 57(9):759-764.

41. Banerjee $D$, Khair OA, Honeybourne D: Impact of sputum bacteria on airway inflammation and health status in clinical stable COPD. Eur Respir J 2004, 23(5):685-691.

42. Sethi S, Maloney J, Grove L, Wrona C, Berenson CS: Airway inflammation and bronchial bacterial colonization in chronic obstructive pulmonary disease. Am J Respir Crit Care Med 2006, 173(9):991-998.

43. Soler N, Ewig S, Torres A, Filella X, Gonzalez J, Zaubet A: Airway inflammation and bronchial microbial patterns in patients with stable chronic obstructive pulmonary disease. Eur Respir J 1999, 14(5):1015-1022.

44. Weinreich UM, Korsgaard J: Bacterial colonisation of lower airways in health and chronic lung disease. Clin Respir J 2008, 2(2):116-122.

45. Wedzicha JA: Role of viruses in exacerbations of chronic obstructive pulmonary disease. Proc Am Thorac Soc 2004, 1(2):115-120.

46. Wilkinson TM, Hurst JR, Perera WR, Wilks M, Donaldson GC, Wedzicha JA: Effect of interactions between lower airway bacterial and rhinoviral infection in exacerbations of COPD. Chest 2006, 129(2):317-324.

47. Matkovic Z, Miravitlles M: Chronic bronchial infection in COPD. Is there an infective phenotype? Respir Med 2013, 107(1):10-22.

48. Kim V, Criner GJ: Chronic bronchitis and chronic obstructive pulmonary disease. Am J Respir Crit Care Med 2013, 187(3):228-237. 
49. Barnes PJ: Chronic obstructive pulmonary disease. N Engl J Med 2000, 343(4):269-280

50. Hurst JR, Perera WR, Wilkinson TM, Donaldson GC, Wedzicha JA: Systemic and upper and lower airway inflammation at exacerbation of chronic obstructive pulmonary disease. Am J Respir Crit Care Med 2006, 173(1):71-78.

51. Pant S, Walters EH, Griffiths A, Wood-Baker R, Johns DP, Reid DW: Airway inflammation and anti-protease defences rapidly improve during treatment of an acute exacerbation of COPD. Respirology 2009, 14(4):495-503.

52. Aaron SD, Angel JB, Lunau M, Wright K, Fex C, Le-Saux N, Dales RE: Granulocyte inflammatory markers and airway infection during acute exacerbation of chronic obstructive pulmonary disease. Am J Respir Crit Care Med 2001, 163(2):349-355.

53. Fujimoto K, Yasuo M, Urushibata K, Hanaoka M, Koizumi T, Kubo K: Airway inflammation during stable and acutely exacerbated chronic obstructive pulmonary disease. Eur Respir J 2005, 25(4):640-646.

54. Perera WR, Hurst JR, Wilkinson TM, Sapsford RJ, Mullerova H, Donaldson GC, Wedzicha JA: Inflammatory changes, recovery and recurrence at COPD exacerbation. Eur Respir J 2007, 29(3):527-534

55. Gompertz S, O'Brien C, Bayley DL, Hill SL, Stockley RA: Changes in bronchial inflammation during acute exacerbations of chronic bronchitis. Eur Respir J 2001, 17(6):1112-1119.

56. Tsoumakidou M, Tzanakis N, Chrysofakis G, Siafakas NM: Nitrosative stress, heme oxygenase- 1 expression and airway inflammation during severe exacerbations of COPD. Chest 2005, 127(6):1911-1918.

57. Bathoorn E, Liesker JJ, Postma DS, Boorsma M, Bondesson E, Koeter GH, Kauffman HF, van-Oosterhout AJ, Kerstjens HA: Anti-inflammatory effects of combined budesonide/formoterol in COPD exacerbations. Copd 2008 , 5(5):282-290.

58. Sethi S, Muscarella K, Evans N, Klingman KL, Grant BJ, Murphy TF: Airway inflammation and etiology of acute exacerbations of chronic bronchitis. Chest 2000, 118(6):1557-1565

59. White AJ, Gompertz S, Bayley DL, Hill SL, O'Brien C, Unsal I, Stockley RA: Resolution of bronchial inflammation is related to bacterial eradication following treatment of exacerbations of chronic bronchitis. Thorax 2003, 58(8):680-685.

60. Hill AT, Campbell EJ, Hill SL, Bayley DL, Stockley RA: Association between airway bacterial load and markers of airway inflammation in patients with stable chronic bronchitis. Am J Med 2000, 109(4):288-295.

61. Bresser $P$, Out TA, van-Alphen $L$, Jansen HM, Lutter R: Airway inflammation in nonobstructive and obstructive chronic bronchitis with chronic haemophilus influenzae airway infection. Comparison with noninfected patients with chronic obstructive pulmonary disease. Am J Respir Crit Care Med 2000, 162(3 Pt 1):947-952.

62. Marin A, Garcia-Aymerich J, Sauleda J, Belda J, Millares L, Garcia-Nunez M, Serra I, Benet M, Agusti A, Anto JM, et al: Effect of bronchial colonisation on airway and systemic inflammation in stable COPD. Copd 2012, 9(2):121-130.

63. Garcha DS, Thurston SJ, Patel AR, Mackay AJ, Goldring JJ, Donaldson GC, McHugh TD, Wedzicha JA: Changes in prevalence and load of airway bacteria using quantitative PCR in stable and exacerbated COPD. Thorax 2012, 67(12):1075-1080.

64. King PT, Lim S, Pick A, Ngui J, Prodanovic Z, Downey W, Choong C, Kelman A, Baranyai $E$, Francis $M$, et al: Lung T-cell responses to nontypeable Haemophilus influenzae in patients with chronic obstructive pulmonary disease. J Allergy Clin Immunol 2013, 131(5):1314-1321. e1314.

65. Mackay AJ, Hurst JR: COPD exacerbations: causes, prevention, and treatment. Immunol Allergy Clin North Am 2013, 33(1):95-115.

66. Stockley RA, Bayley D, Hill SL, Hill AT, Crooks S, Campbell EJ: Assessment of airway neutrophils by sputum colour: correlation with airways inflammation. Thorax 2001, 56(5):366-372

67. Stockley RA, O'Brien C, Pye A, Hill SL: Relationship of sputum color to nature and outpatient management of acute exacerbations of COPD. Chest 2000, 117(6):1638-1645.

68. Nagendra S, Bourbeau P, Brecher S, Dunne M, LaRocco M, Doern G: Sampling variability in the microbiological evaluation of expectorated sputa and endotracheal aspirates. J Clin Microbio/ 2001, 39(6):2344-2347.

69. Cooper GM, Jones JJ, Arbique JC, Flowerdew GJ, Forward KR: Intra and inter technologist variability in the quality assessment of respiratory tract specimens. Diagn Microbiol Infect Dis 2000, 37(4):231-235.

70. Geckler RW, Gremillion DH, McAllister CK, Ellenbogen C: Microscopic and bacteriological comparison of paired sputa and transtracheal aspirates. J Clin Microbiol 1977, 6(4):396-399.
71. Gleckman R, DeVita J, Hibert D, Pelletier C, Martin R: Sputum gram stain assessment in community-acquired bacteremic pneumonia. J Clin Microbiol 1988, 26(5):846-849.

72. Murdoch DR: Nucleic acid amplification tests for the diagnosis of pneumonia. Clin Infect Dis 2003, 36(9):1162-1170.

73. Loens K, Ursi D, Goossens H, leven M: Molecular diagnosis of Mycoplasma pneumoniae respiratory tract infections. J Clin Microbiol 2003, 41(11):4915-4923.

74. Wimberley N, Faling $\sqcup$, Bartlett JG: A fiberoptic bronchoscopy technique to obtain uncontaminated lower airway secretions for bacterial culture. Am Rev Respir Dis 1979, 119(3):337-343.

75. Thorpe JE, Baughman RP, Frame PT, Wesseler TA, Staneck JL: Bronchoalveolar lavage for diagnosing acute bacterial pneumonia. $J$ Infect Dis 1987, 155(5):855-861.

76. Rasmussen TR, Korsgaard J, Moller JK, Sommer T, Kilian M: Quantitative culture of bronchoalveolar lavage fluid in community-acquired lower respiratory tract infections. Respir Med 2001, 95(11):885-890.

77. Moller LV, Regelink AG, Grasselier H, Dankert-Roelse JE, Dankert J, van-Alphen L: Multiple Haemophilus influenzae strains and strain variants coexist in the respiratory tract of patients with cystic fibrosis. J Infect Dis 1995, 172(5):1388-1392

78. Wilson RW: Host-bacterial interactions and chronic bronchitis. In Respiratory Infections. Edited by Torres A, Ewig S, Mandell A, Woodhead M. London: Hodder Arnold; 2006:89-102.

79. Saint S, Bent S, Vittinghoff E, Grady D: Antibiotics in chronic obstructive pulmonary disease exacerbations. A meta-analysis. Jama 1995, 273(12):957-960

80. Miravitlles $M$, Torres $A$ : No more equivalence trials for antibiotics in exacerbations of COPD, please. Chest 2004, 125(3):811-813.

81. Anthonisen NR, Manfreda J, Warren CP, Hershfield ES, Harding GK, Nelson NA: Antibiotic therapy in exacerbations of chronic obstructive pulmonary disease. Ann Intern Med 1987, 106(2):196-204.

82. Llor C, Moragas A, Hernandez S, Bayona C, Miravitlles M: Efficacy of antibiotic therapy for acute exacerbations of mild to moderate chronic obstructive pulmonary disease. Am J Respir Crit Care Med 2012, 186 (8):716-723.

83. Soler N, Esperatti M, Ewig S, Huerta A, Agusti C, Torres A: Sputum purulence-guided antibiotic use in hospitalised patients with exacerbations of COPD. Eur Respir J 2012, 40(6):1344-1353.

84. Christ-Crain M, Jaccard-Stolz D, Bingisser R, Gencay MM, Huber PR, Tamm M, Muller B: Effect of procalcitonin-guided treatment on antibiotic use and outcome in lower respiratory tract infections: cluster-randomised, single-blinded intervention trial. Lancet 2004, 363(9409):600-607.

85. Stolz D, Christ-Crain M, Bingisser R, Leuppi J, Miedinger D, Muller C, Huber $P$, Muller B, Tamm M: Antibiotic treatment of exacerbations of COPD: a randomized, controlled trial comparing procalcitonin-guidance with standard therapy. Chest 2007, 131(1):9-19.

86. MacNee W: Systemic inflammatory biomarkers and co-morbidities of chronic obstructive pulmonary disease. Ann Med 2013, 45(3):291-300.

87. Staykova T, Black PN, Chacko EE, Poole P: Prophylactic antibiotic therapy for chronic bronchitis. Cochrane Database Syst Rev 2003, 1, CD004105.

88. Seemungal TA, Wilkinson TM, Hurst JR, Perera WR, Sapsford RJ, Wedzicha JA: Long-term erythromycin therapy is associated with decreased chronic obstructive pulmonary disease exacerbations. Am J Respir Crit Care Med 2008, 178(11):1139-1147.

89. Yamaya M, Azuma A, Tanaka H, Takizawa H, Chida K, Taguchi Y, Mikasa K, Kadota J, Kudoh S: Inhibitory effects of macrolide antibiotics on exacerbations and hospitalization in chronic obstructive pulmonary disease in Japan: a retrospective multicenter analysis. J Am Geriatr Soc 2008, 56(7):1358-1360.

90. He ZY, Ou LM, Zhang JQ, Bai J, Liu GN, Li MH, Deng JM, MacNee W, Zhong XN: Effect of 6 months of erythromycin treatment on inflammatory cells in induced sputum and exacerbations in chronic obstructive pulmonary disease. Respiration 2010, 80(6):445-452.

91. Blasi F, Bonardi D, Aliberti S, Tarsia P, Confalonieri M, Amir O, Carone M, Di-Marco F, Centanni S, Guffanti E: Long-term azithromycin use in patients with chronic obstructive pulmonary disease and tracheostomy. Pulm Pharmacol Ther 2010, 23(3):200-207.

92. Patel IS, Vlahos I, Wilkinson TM, Lloyd-Owen SJ, Donaldson GC, Wilks M, Reznek RH, Wedzicha JA: Bronchiectasis, Exacerbation Indices and Inflammation in Chronic Obstructive Pulmonary Disease. Am J Respir Crit Care Med 2004, 170(4):400-407. 
93. O'Brien C, Guest PJ, Hill SL, Stockley RA: Physiological and radiological characterisation of patients diagnosed with chronic obstructive pulmonary disease in primary care. Thorax 2000, 55(8):635-642.

94. Wong C, Jayaram L, Karalus N, Eaton T, Tong C, Hockey H, Milne D, Fergusson W, Tuffery C, Sexton P, et al: Azithromycin for prevention of exacerbations in non-cystic fibrosis bronchiectasis (EMBRACE): a randomised, double-blind, placebo-controlled trial. Lancet 2012, 380(9842):660-667.

95. Serisier DJ, Martin ML, MCGuckin MA, Lourie R, Chen AC, Brain B, Biga S, Schlebusch S, Dash P, Bowler SD: Effect of long-term, low-dose erythromycin on pulmonary exacerbations among patients with non-cystic fibrosis bronchiectasis: the BLESS randomized controlled trial. Jama 2013, 309(12):1260-1267.

96. Wenzel RP, Fowler AA 3rd, Edmond MB: Antibiotic prevention of acute exacerbations of COPD. N Engl J Med 2012, 367(4):340-347.

97. Ray WA, Murray KT, Hall K, Arbogast PG, Stein CM: Azithromycin and the risk of cardiovascular death. N Engl J Med 2012, 366(20):1881-1890.

98. Svanstrom H, Pasternak B, Hviid A: Use of azithromycin and death from cardiovascular causes. N Engl J Med 2013, 368(18):1704-1712.

99. Pesek R, Lockey R: Vaccination of adults with asthma and COPD. Allergy 2011, 66(1):25-31.

100. Poole PJ, Chacko E, Wood-Baker RW, Cates CJ: Influenza vaccine for patients with chronic obstructive pulmonary disease. Cochrane Database Syst Rev 2006, 1, CD002733.

101. Ansaldi F, Turello V, Lai P, Bastone G, De-Luca S, Rosselli R, Durando P, Sticchi L, Gasparini R, Delfino E, et al: Effectiveness of a 23-valent polysaccharide vaccine in preventing pneumonia and non-invasive pneumococcal infection in elderly people: a large-scale retrospective cohort study. J Int Med Res 2005, 33(5):490-500.

102. Lee TA, Weaver FM, Weiss KB: Impact of pneumococcal vaccination on pneumonia rates in patients with COPD and asthma. J Gen Intern Med 2007, 22(1):62-67.

103. Vila-Corcoles A, Ochoa-Gondar O, Guzman JA, Rodriguez-Blanco T, Salsench E, Fuentes CM: Effectiveness of the 23-valent polysaccharide pneumococcal vaccine against invasive pneumococcal disease in people 60 years or older. BMC Infect Dis 2010, 10:73.

104. Granger R, Walters J, Poole PJ, Lasserson TJ, Mangtani P, Cates CJ, Wood-Baker R: Injectable vaccines for preventing pneumococcal infection in patients with chronic obstructive pulmonary disease. Cochrane Database Syst Rev 2006, 4, CD001390.

105. Clancy R, Cripps A, Murree-Allen K, Yeung S, Engel M: Oral immunisation with killed Haemophilus influenzae for protection against acute bronchitis in chronic obstructive lung disease. Lancet 1985, 2(8469-70):1395-1397.

106. Tandon MK, Phillips M, Waterer G, Dunkley M, Comans P, Clancy R: Oral immunotherapy with inactivated nontypeable Haemophilus influenzae reduces severity of acute exacerbations in severe COPD. Chest 2010, 137(4):805-811.

107. Roede BM, Bresser P, Bindels PJ, Kok A, Prins M, ter-Riet G, Geskus RB, Herings RM, Prins JM: Antibiotic treatment is associated with reduced risk of a subsequent exacerbation in obstructive lung disease: an historical population based cohort study. Thorax 2008, 63(11):968-973.

108. Cates C: Inhaled corticosteroids in COPD: quantifying risks and benefits. Thorax 2012, 68(6):499-500.

109. Hayden FG, Herrington DT, Coats TL, Kim K, Cooper EC, Villano SA, Liu S, Hudson S, Pevear DC, Collett M, et al: Efficacy and safety of oral pleconaril for treatment of colds due to picornaviruses in adults: results of 2 double-blind, randomized, placebo-controlled trials. Clin Infect Dis 2003, 36(12):1523-1532.

110. Calverley PM, Rabe KF, Goehring UM, Kristiansen S, Fabbri LM, Martinez FJ: Roflumilast in symptomatic chronic obstructive pulmonary disease: two randomised clinical trials. Lancet 2009, 374(9691):685-694.

111. Fabbri LM, Calverley PM, Izquierdo-Alonso JL, Bundschuh DS, Brose M, Martinez FJ, Rabe KF: Roflumilast in moderate-to-severe chronic obstructive pulmonary disease treated with longacting bronchodilators: two randomised clinical trials. Lancet 2009, 374(9691):695-703.
112. Decramer M, Rutten-van Molken M, Dekhuijzen PN, Troosters $T$, van-Herwaarden C, Pellegrino $R$, van-Schayck CP, Olivieri D, Del-Donno M, de-Backer W, et al: Effects of N-acetylcysteine on outcomes in chronic obstructive pulmonary disease (Bronchitis Randomized on NAC Cost-Utility Study, BRONCUS): a randomised placebo-controlled trial. Lancet 2005, 365(9470):1552-1560.

113. Forsythe P: Probiotics and lung diseases. Chest 2011, 139(4):901-908.

doi:10.1186/2213-0802-1-13

Cite this article as: King et al:: Bacteria in COPD; their potential role and treatment. Translational Respiratory Medicine 2013 1:13.

\section{Submit your manuscript to a SpringerOpen ${ }^{\circ}$ journal and benefit from:}

- Convenient online submission

- Rigorous peer review

- Immediate publication on acceptance

- Open access: articles freely available online

- High visibility within the field

- Retaining the copyright to your article

Submit your next manuscript at $>$ springeropen.com 